\title{
Loss of phosphorus by runoff from soils after amendment with poultry litter co-composted with crop waste
}

\author{
Asma Saleem $^{1} \cdot$ Muhammad Irshad $^{1,2} \cdot$ An Ping $^{2} \cdot$ Bushra Haroon $^{1}$ \\ Received: 10 November 2017 / Accepted: 7 April 2018 / Published online: 25 April 2018 \\ (c) The Author(s) 2018
}

\begin{abstract}
Purpose The study aimed to assess the influence of poultry litter (PL) after co-composting with sugarcane and cabbage waste on phosphorus $(\mathrm{P})$ losses in runoff from soils under natural rainfall conditions.

Methods Co-composted PL was amended in silt loam and sandy clay soils. The soil applied with PL without agro-waste was considered as control treatment. Before the soil application, PL was co-composted with agro-wastes, i.e., sugarcane waste and cabbage waste at four levels $(0,25,33$, and 50\%). Soils were packed in wooden trays layered with plastic. The surface soil was mixed with the co-composted PL at rates 200 and $400 \mathrm{~kg} \mathrm{P} \mathrm{ha}^{-1}$. Runoff samples were collected from the sloped trays during two rainfall events and $\mathrm{P}$ concentration was determined.

Results Phosphorus concentration was found higher in the runoff in the PL treatment without agro-waste. Poultry litter application along with agro-waste profoundly lowered $\mathrm{P}$ losses in the runoff as compared to the control especially at higher application of agro-waste. Application of PL composted with higher level of agro-waste (\%) reduced the P losses from soils. Phosphorus losses in the runoff enhanced with higher amount of PL application depending on the soil type and initial P content in the soil. Silt loam soil amended with co-composted poultry litter/agro-waste reduced P losses more significantly as compared to sandy clay soil.

Conclusion The application of manure amendments with agro-wastes decreased the losses of soluble P and would reduce detrimental environmental effects.
\end{abstract}

Keyword Phosphorus loss $\cdot$ Runoff $\cdot$ Rainfall events $\cdot$ Poultry litter $\cdot$ Crop waste

\section{Introduction}

Surface runoff is causing phosphorus $(\mathrm{P})$ losses from soil which is responsible for eutrophication of water bodies (Pote et al. 1999). A well-established correlation between agricultural P losses to surface waters and eutrophication has been reported (Cassell et al. 1998; Correll 1998). Phosphorus application can result in increased risk of $\mathrm{P}$ delivery to surface waters. Application of excessive manure to soils for the longer period increases the $\mathrm{P}$ level in soil and/or surface water (Sharpley et al. 2004). Phosphorus is added to soil in

Muhammad Irshad

mirshad@ciit.net.pk

1 Department of Environmental Sciences, COMSATS Institute of Information Technology Abbottabad, Abbottabad, Pakistan

2 Arid Land Research Center Tottori University, Hamasaka cho, Tottori 680-0001, Japan the form of organic waste (Brogan et al. 2001). The use of poultry litter on the agricultural lands with elevated $P$ levels needs special management. Fresh poultry litter may quickly release $\mathrm{P}$ in soil, whereas stable forms of organic matter may slowly release $\mathrm{P}$ sources. Composting is a biological process of decomposition in which organic matter is transformed to a stable product like humus. The process is carried out by microbes, which use organic waste for food and energy purposes (Chefetz et al. 1998). Composting of organic wastes is important due to the environmental and community constraints and enhanced agronomic value. McDowell and Sharpley (2003) reported the potential of soil P losses into runoff after application of P-containing materials. The release of $\mathrm{P}$ from soil to runoff has been well reported by the kinetics of $\mathrm{P}$ desorption from soil (Sharpley et al. 1981; Garcia-Rodeja and Gil-Sotres 1997). The salient P mobility controlling factors in surface runoff are transport and source such as manure or fertilizer (Pote et al. 1996; Sharpley et al. 1993). Runoff from cropland areas receiving poultry litter 
or compost may enhance $\mathrm{P}$ concentrations in water bodies (Eghball et al. 1996). The environmental issues related to poultry manure and agricultural residues application could be alleviated by composting before application to agricultural fields. Therefore, the present research was aimed to assess P losses from soils amended with poultry litter after co-composting with agro-wastes.

\section{Materials and methods}

Poultry litter (PL) was brought from poultry farms around Abbottabad, where these farms were in abundance. The wastes of sugarcane (Saccharum officinarum) and cabbage (Brassica oleracea var. capitata) collected from vegetable market of Abbottabad city $\left(34.1558^{\circ} \mathrm{N}, 73.2194^{\circ} \mathrm{E}\right)$, Pakistan. These wastes were cut into smaller pieces $<5 \mathrm{~cm}$. The PL was co-composted with sugarcane waste (SW) and cabbage waste $(\mathrm{CW})$ in plastic bins $(>10 \mathrm{~L})$ arranged in rows inside a tiled shed to protect from the rain. Poultry litter was mixed with $\mathrm{SW}$ and $\mathrm{CW}$ separately at three levels, i.e., 25,33 , and $50 \%$. Poultry litter after composting without agro-waste was set as a control treatment. The material was co-composted for 120 days. The treatments were replicated thrice. The material was moistened periodically and aerated during the composting process. Additional water was added as required and moisture content in the poultry manure was kept at $30 \%$. Samples were collected after mixing, and then air dried, crushed, and sieved $(<0.5 \mathrm{~mm})$ to ensure homogeneity. The physico-chemical properties of the composted manure samples were determined (Table 1).

Total carbon was determined using dry-combustion method (Nelson and Sommers 1982). pH and EC were measured in manure and soil samples also. The $\mathrm{pH}$ was determined in the manure suspension with manure: water ratio of $1: 5$ by a pH meter (Model: HANNA HI 8520). Electrical conductivity (EC) in the manure suspension before and after composting was measured by an EC meter (Model: 4320 JENWAY) (in 1:5 water suspension). For total nitrogen, Kjeldahl $\mathrm{N}$ determination was performed according to APHA (1995). Total Kjeldahl nitrogen was estimated by digesting the compost sample in concentrated sulphuric acid and by distillation and trapping the ammonia in $0.1 \mathrm{~N}$ sulphuric acid titrated against standard $0.1 \mathrm{~N}$ sodium hydroxide solution (AOAC 1995). Carbon-to-nitrogen ratio was calculated based on the total $\mathrm{C}$ and total Kjeldahl $\mathrm{N}$ concentrations. Sample weighing $0.5 \mathrm{~g}$ was digested within a mixture (1:3) of per chloric $\left(\mathrm{HClO}_{4}\right)$ and nitric $\left(\mathrm{HNO}_{3}\right)$ acids for the determination of total concentrations of macro- and microelements [potassium $(\mathrm{K})$, calcium $(\mathrm{Ca})$, magnesium $(\mathrm{Mg})$, sodium $(\mathrm{Na})$, copper $(\mathrm{Cu})$, iron $(\mathrm{Fe})$, manganese $(\mathrm{Mn})$, and zinc $(\mathrm{Zn})$ ], using an atomic absorption spectrophotometer (AAS) (Miller 1998). Total phosphorus (P) in the digest was
Table 1 Chemical properties of poultry litter and agro-wastes before composting

\begin{tabular}{lccl}
\hline Parameters & Poultry litter & Sugarcane waste & Cabbage waste \\
\hline $\mathrm{pH}(1: 5)$ & 7.8 & 6.8 & 2.6 \\
$\mathrm{EC}\left(\mathrm{dS} \mathrm{m}^{-1}\right)$ & 9.4 & 2.7 & 0.2 \\
Total C $\left(\mathrm{g} \mathrm{kg}^{-1}\right)$ & 440.6 & 636 & 490 \\
$\mathrm{C}: \mathrm{N}$ & 16 & 57 & 40 \\
Total Ca $\left(\mathrm{mg} \mathrm{kg}^{-1}\right)$ & 1234 & 307 & 500 \\
Total Mg & 409 & 187 & 120 \\
$\quad\left(\mathrm{mg} \mathrm{kg}^{-1}\right)$ & & & \\
Total Na $\left(\mathrm{mg} \mathrm{kg}^{-1}\right)$ & 222 & 185 & 180 \\
Total P $\left(\mathrm{g} \mathrm{kg}^{-1}\right)$ & 13.6 & 5.3 & 0.26 \\
Total K $\left(\mathrm{mg} \mathrm{kg}^{-1}\right)$ & 721 & 8.1 & 1.7 \\
Total N $\left(\mathrm{g} \mathrm{kg}^{-1}\right)$ & 50.6 & 11.9 & 5.3 \\
Total Fe $\left(\mathrm{mg} \mathrm{kg}^{-1}\right)$ & 299 & 35.8 & 1.7 \\
Total Cu & 89 & 1.5 & 2.6 \\
$\quad\left(\mathrm{mg} \mathrm{kg}^{-1}\right)$ & & & 0.3 \\
Total Mn & 255 & 2.2 & 1.8 \\
$\quad\left(\mathrm{mg} \mathrm{kg}^{-1}\right)$ & & & \\
Total Zn $\left(\mathrm{mg} \mathrm{kg}^{-1}\right)$ & 158 & 12.9 &
\end{tabular}

determined by phospho-molybdate blue color method and absorbance was measured by a spectrophotometer at a wavelength of $710 \mathrm{~nm}$ (Olsen and Sommers 1982). Composted PL samples were fractionated into readily plant-available $\mathrm{P}$, labile inorganic $\mathrm{P}$ (another plant-available fraction), sesquioxide-associated ( $\mathrm{Fe}$ oxide and $\mathrm{Al}$ oxide) inorganic $\mathrm{P}$ - and $\mathrm{Ca}$-associated $\mathrm{P}$ by sequential extraction with deionized water, $0.5 \mathrm{M} \mathrm{NaHCO}_{3}(\mathrm{pH} 8.5$ ), $0.1 \mathrm{M} \mathrm{NaOH}$, and $1 \mathrm{M} \mathrm{HCl}$. The sequential extraction of inorganic $\mathrm{P}$ used in this study was as follows: $0.1 \mathrm{~g}$ sample of the compost $(0.5 \mathrm{~mm})$ was placed in a $50 \mathrm{~mL}$ centrifuge tube and was sequentially extracted with $30 \mathrm{~mL}$ each of de-ionized water, $0.5 \mathrm{M} \mathrm{NaHCO}_{3}, 0.1 \mathrm{M} \mathrm{NaOH}$, and $1 \mathrm{M} \mathrm{HCl}$. The extraction with each reagent was carried out in duplicate after $16 \mathrm{~h}$ of end-to-end shaking. After each shaking, tubes were shaken for $16 \mathrm{~h}$ at room temperature and centrifuged at $10000 \mathrm{rpm}$ for $15 \mathrm{~min}$. Supernatants were filtered and the P contents determined calorimetrically using the molybdenum blue method (Olsen and Sommers 1982).

\section{Runoff experiment}

A separate study was carried out to determine P losses from soils amended with composted manures. Soils were sampled from a depth of 0-20 cm from different sites of Abbottabad, where the annual rainfall occurred about $1160 \mathrm{~mm}$. The physico-chemical properties of soils analyzed are given in Table 2. Soil texture was determined using pipette method (Gee and Bauder 1986). Soils were classified as silt loam and sandy clay based on textural analysis. Soil samples were sieved via a $2 \mathrm{~mm}$ sieve and packed with $10 \mathrm{~kg}$ soil in the 
Table 2 Chemical composition of soils used for the study

\begin{tabular}{llcc}
\hline Parameters & Unit & Silt loam & Sandy clay \\
\hline Total C & $\mathrm{g} \mathrm{kg}^{-1}$ & 26.9 & 31.4 \\
Total $\mathrm{N}$ & $\mathrm{mg} \mathrm{kg}^{-1}$ & 51.3 & 63.8 \\
Total $\mathrm{P}$ & $\mathrm{mg} \mathrm{kg}^{-1}$ & 59.3 & 75.8 \\
Total Ca & $\mathrm{mg} \mathrm{kg}^{-1}$ & 259.1 & 300.2 \\
Total $\mathrm{Mg}$ & $\mathrm{mg} \mathrm{kg}^{-1}$ & 125.2 & 151.6 \\
Total $\mathrm{K}$ & $\mathrm{mg} \mathrm{kg}^{-1}$ & 149.9 & 157.6 \\
Total Na & $\mathrm{mg} \mathrm{kg}^{-1}$ & 29.1 & 37.3 \\
Total Cu & $\mathrm{mg} \mathrm{kg}^{-1}$ & 48.3 & 61.7 \\
Total Fe & $\mathrm{mg} \mathrm{kg}^{-1}$ & 69.6 & 61.6 \\
Total Mn & $\mathrm{mg} \mathrm{kg}^{-1}$ & 61.5 & 75.5 \\
Total Zn & $\mathrm{mg} \mathrm{kg}^{-1}$ & 71.3 & 103.8 \\
Total $\mathrm{Ni}$ & $\mathrm{mg} \mathrm{kg}^{-1}$ & 2.3 & 2.7 \\
Total Cd & $\mathrm{mg} \mathrm{kg}^{-1}$ & 0.7 & 1.3 \\
EC (1:5) & $\mathrm{dS} \mathrm{m}^{-1}$ & 0.6 & 0.9 \\
pH (1:5) & & 7.6 & 7.1 \\
\hline
\end{tabular}

wooden trays layered at the bottom and sides with plastic sheets (tray size: $0.5 \mathrm{~m} \times 0.5 \mathrm{~m} \times 0.2 \mathrm{~m}$ ). Soils in the trays were moistened to field capacity. The trays were installed in an open field. The outlet of each tray was connected to a plastic container. The trays were placed at a 5\% slope. Triplicate trays were used for each treatment. Co-composted material was applied at the rate of 200 and $400 \mathrm{~kg}$ total $\mathrm{P} \mathrm{ha}^{-1}$. Surface runoff was collected in plastic bottles at the down slope end of the trays to evaluate runoff $\mathrm{P}$ losses. Time, duration, and precipitation level was determined by the automated weather station of CIIT Abbottabad. The data were collected after two consecutive rainfall events. Phosphorus contents in the runoff were determined to compare the loss of $\mathrm{P}$ from co-compost treated soil and untreated soil.

\section{Statistical analysis}

The data were statistically analyzed and analysis of variance (ANOVA) was done using Stat-view software. The least significant difference (LSD) was determined at $P \leq 0.05$ to calculate significant differences between treatments.

\section{Results and discussion}

Total P concentrations were found as $21.8,19.6,17.2$, and $15.5 \mathrm{~g} \mathrm{~kg}^{-1}$ with the sugarcane waste (SW) at the application rate of $0,25,33$, and $50 \%$, respectively, after 120 days of composting. With the incorporation of cabbage waste (CW), the concentrations were $18.1,16.7$, and $15.1 \mathrm{~g} \mathrm{~kg}^{-1}$, respectively (Table 3 ). The reduced organic $\mathrm{P}$ in the compost could be related to the lower $\mathrm{P}$ content in the plant waste when compared with the manure. Organic $\mathrm{P}$ in the control poultry litter was higher than that in the plantwaste treatments. However, the blending of poultry litter with the SW and CW reduced the $\mathrm{P}$ contents. The $\mathrm{P}$ fractions differed in the composted manure as $\mathrm{HCl}-\mathrm{P}>$ water$\mathrm{P}>\mathrm{NaHCO} 3-\mathrm{P}>\mathrm{NaOH}-\mathrm{P}$. Sugarcane waste amendment gave higher concentrations of $\mathrm{P}$ across all fractions than CW.

Phosphorus concentrations in the runoff were higher under the compost treatment without crop waste (Table 4). Poultry litter application along with agro-waste profoundly lowered P losses in the runoff as compared to the control. Phosphorus contents in the runoff decreased with the increasing ratio of agro-wastes in the compost treated soils. Phosphorus losses in the runoff were higher with the higher manure application rate. Silt loam soil amended with co-composted poultry litter/agro-waste reduced $\mathrm{P}$ losses more significantly as compared to sandy clay soil.

The differences in the $\mathrm{P}$ losses could be associated with the difference in the initial $\mathrm{P}$ content and soil texture. $\mathrm{P}$ contents in silt loam soil ranged from 31.2 to $24.5 \mathrm{mg}$ $\mathrm{L}^{-1}$ after application $200 \mathrm{~kg} \mathrm{P} \mathrm{ha}^{-1}$ followed by 36.7 to $32.1 \mathrm{mg} \mathrm{L}^{-1}$ after application of $400 \mathrm{~kg} \mathrm{P} \mathrm{ha}^{-1}$ with poultry litter: sugarcane waste (SW) mixture, respectively, as compared to the sandy clay containing 35.5 to $31.2 \mathrm{mg}$ $\mathrm{L}^{-1}$ in $200 \mathrm{~kg} \mathrm{P} \mathrm{ha}^{-1}$ followed by 39.7 to $35.4 \mathrm{mg} \mathrm{L}^{-1}$ at application rate of $400 \mathrm{~kg} \mathrm{P} \mathrm{ha}^{-1}$. Compost without agrowaste contained $40.6 \mathrm{mg} \mathrm{L}^{-1}$ in silt loam and $44.1 \mathrm{mg}$ $\mathrm{L}^{-1} \mathrm{P}$ contents in runoff in sandy clay soil in SW-poultry litter. The study showed that co-compost containing agrowaste reduced $\mathrm{P}$ contents more effectively in the runoff.
Table 3 Phosphorus fractions $\left(\mathrm{g} \mathrm{kg}^{-1}\right)$ in poultry litter after co-composting for 120 days with sugarcane and cabbage waste at different ratios

\begin{tabular}{lcccccc}
\hline & Waste application (\%) & Total & $\mathrm{H}_{2} \mathrm{O}$ & $\mathrm{NaHCO}_{3}$ & $\mathrm{NaOH}$ & $\mathrm{HCl}$ \\
\hline Sugarcane waste & 0 & 21.8 & 8.6 & 3.5 & 1.9 & 12.7 \\
& 25 & 19.6 & 6.8 & 1.7 & 1.5 & 10.7 \\
& 33 & 17.2 & 4.3 & 0.9 & 1.3 & 8.7 \\
Cabbage waste & 50 & 15.5 & 3.8 & 0.6 & 1.0 & 7.1 \\
& 25 & 18.1 & 6.5 & 1.2 & 1.3 & 9.0 \\
& 33 & 16.7 & 4.0 & 0.5 & 1.7 & 8.1 \\
& 50 & 15.1 & 3.0 & 0.2 & 0.9 & 6.8 \\
& LSD (0.05) & 1.5 & 0.7 & 0.03 & 0.1 & 0.2 \\
\hline
\end{tabular}


Table 4 Average phosphorus loss in runoff after two rainfall events from soils treated with co-composted poultry litter with agro-wastes at two application rates

\begin{tabular}{|c|c|c|c|c|}
\hline \multirow[t]{2}{*}{ Agro-waste } & \multirow[t]{2}{*}{ Soil } & \multirow[t]{2}{*}{ Agro-waste in PL (\%) } & $200 \mathrm{~kg} \mathrm{P} \mathrm{ha}^{-1}$ & $400 \mathrm{~kg} \mathrm{P} \mathrm{ha}^{-1}$ \\
\hline & & & \multicolumn{2}{|c|}{$\mathrm{P}$ in runoff $\left(\mathrm{mg} \mathrm{L}^{-1}\right)$} \\
\hline \multirow[t]{9}{*}{ Sugarcane waste } & \multirow[t]{4}{*}{ Silt loam } & 0 & 40.6 & 43.4 \\
\hline & & 25 & 31.2 & 36.7 \\
\hline & & 33 & 27.4 & 34.4 \\
\hline & & 50 & 24.5 & 32.1 \\
\hline & \multirow[t]{5}{*}{ Sandy clay } & 0 & 44.1 & 47.8 \\
\hline & & 25 & 34.5 & 39.7 \\
\hline & & 33 & 32.7 & 37.4 \\
\hline & & 50 & 30.2 & 35.4 \\
\hline & & $\operatorname{LSD}(0.05)$ & 2.4 & 2.3 \\
\hline \multirow[t]{7}{*}{ Cabbage waste } & \multirow[t]{3}{*}{ Silt loam } & 25 & 26.3 & 31.2 \\
\hline & & 33 & 24.2 & 27.5 \\
\hline & & 50 & 21.1 & 25.1 \\
\hline & \multirow[t]{4}{*}{ Sandy clay } & 25 & 30.9 & 35.3 \\
\hline & & 33 & 28.6 & 33.6 \\
\hline & & 50 & 26.1 & 31.7 \\
\hline & & $\operatorname{LSD}(0.05)$ & 2.6 & 3.1 \\
\hline
\end{tabular}

Regardless of soil and application rates, $\mathrm{P}$ losses in the runoff were lowered with manure co-composted with cabbage waste in the order of (\%) $50>33>25>0$. Sandy clay soil decreased $\mathrm{P}$ contents as $30.9,28.6$, and $26.1 \mathrm{mg} \mathrm{L}^{-1}$ followed by $35.3,33.6$, and $31.7 \mathrm{mg} \mathrm{L}^{-1}$ after application of 25,33 , and $50 \%$ cabbage waste mixture in poultry manure amendment at $200 \mathrm{~kg} \mathrm{P} \mathrm{ha}^{-1}$ and $400 \mathrm{~kg} \mathrm{P}^{-1}$, respectively. Phosphorus losses increased with higher manure applications. Waste mixture at $50 \%$ in the poultry litter reduced maximum losses of $\mathrm{P}$ in the runoff. Spargo et al. (2006) reported higher infiltration and lower runoff from the soils after amendment with co-composted poultry litter and yard waste due to the improvement in soil physical properties and compared poultry litter to poultry litter and yard waste co-compost to reduce $\mathrm{P}$ contents in runoff. Gilley et al. (2002) reported that manure and compost application in disked soil did not increase dissolved and bioavailable fractions of $\mathrm{P}$ in runoff volume, but increased total $\mathrm{P}$ in runoff.

Tillage with cattle manure application significantly lowered dissolved $\mathrm{P}$, particulate $\mathrm{P}$, and total $\mathrm{P}$, whilst disking with cattle manure amendment did not significantly reduce $\mathrm{P}$ constituents in the runoff volume (Gilley et al. 2007). Phosphorus losses were highly affected by the soil application rates of manure amendments mixed with sugarcane and cabbage waste. This substantial reduction of phosphorus losses in the bulk of runoff could be attributed to an increase in the water stable aggregates in soils after co-composts and compost application (McDowell and Sharpley 2001). Tarkalson and Mikkelsen (2007) had also supported an increased total P loss with increased application rates of broiler litter. Gilley et al. (2002) previously reported that, while manure and compost application to soil did not increase dissolved and bioavailable fractions of $\mathrm{P}$ in the runoff volume, they did increase the total amount of $\mathrm{P}$ in runoff. The observed substantial reduction of nutrient losses from soil to runoff was attributed to an increase in water stable aggregates in soils after co-composts and compost application (McDowell and Sharpley 2001). Tejada et al. (2009) also reported the importance of organic amendments in ameliorating soil composition by accommodating the stimulation and development of flocculation of clay minerals, which further promoted aggregation of soil particle.

\section{Conclusions}

It is concluded that compost application without agrowaste increased soil P losses. Co-compost of PL and agro-waste reduced $\mathrm{P}$ losses from soils. Soils amended with increasing ratios of sugarcane and cabbage waste in poultry litter apparently reduced $\mathrm{P}$ concentrations in the runoff. It is concluded that application of manure amendments with agro-wastes found to be a useful option in reducing $\mathrm{P}$ losses from soils. Further studies are needed to investigate the alterations in the soil physico-chemical properties after annual applications of composted manures in agricultural fields.

Acknowledgements The authors are thankful to the Higher Education Commission of Pakistan for funding this research through national research program for universities (NRPU-4831). 
Open Access This article is distributed under the terms of the Creative Commons Attribution 4.0 International License (http://creativecommons.org/licenses/by/4.0/), which permits unrestricted use, distribution, and reproduction in any medium, provided you give appropriate credit to the original author(s) and the source, provide a link to the Creative Commons license, and indicate if changes were made.

\section{References}

Brogan J, Crowe M, Carty G (2001) Developing a national phosphorus balance for agriculture in Ireland. Environmental Protection Agency, Wexford

Cassell EA, Dorioz JM, Kort RL, Hoffmann JP, Meals DW, Kirschtel D, Braun DC (1998) Modeling phosphorus dynamics in ecosystems: mass balance and dynamic simulation approaches. J Environ Qual 27:293-298

Chefetz BF, Adani P, Genevini F, Tambone Hadar Y, Chen Y (1998) Humic-acid transformation during composting of municipal solid waste. J Environ Qual 27:794-800. https://doi.org/10.2134/jeq19 98.00472425002700040011x

Correll DL (1998) The role of phosphorus in the eutrophication of receiving waters: a review. J Environ Qual 27:261-266

Eghball B, Binford GD, Baltensperger DD (1996) Phosphorus movement and adsorption in a soil receiving long-term manure and fertilizer application. J Environ Qual 25:1339-1343. https://doi. org/10.2134/jeq1996.00472425002500060024x

Garcia-Rodeja I, Gil-Sotres F (1997) Prediction of parameters describing phosphorus-desorption kinetics in soils of Galicia (Northwest Spain). J Environ Qual 26:1363-1369. https://doi.org/10.2134/ jeq1997.00472425002600050023x

Gee GW, Bauder JW (1986) Particle-size analysis. In: Klute A (ed), Method of Soil Analysis, Part 1, Agronomy series No. 9. Am. Soc. Agron. Soil Sci. Soc. Am. Inc Publ, Madison WI, USA, pp 383-441

Gilley JE, Risse LM, Eghball B (2002) Managing runoff following manure application. J Soil Water Conserv 57(6):530-533

Gilley JE, Eghball B, Marx DB (2007) Nutrient concentrations of runoff during the year following manure application. Trans ASABE 50(6):1987-1999

McDowell RW, Sharpley AN (2001) Approximating phosphorus release from soils to surface runoff and subsurface drainage. $\mathrm{J}$ Environ Qual 30:508-520. https://doi.org/10.2134/jeq2001.30250 $8 \mathrm{x}$
McDowell RW, Sharpley A (2003) The effects of soil carbon on phosphorus and sediment loss from soil trays by over land flow. J Environ Qual 32:207-214. https://doi.org/10.2134/jeq2003.2070

Miller RO (1998) Nitric-perchloric acid wet digestion in an open vessel. In: Kalra Y (ed) Handbook of reference methods for plant analysis. CRC Press, Washington, DC

Nelson DW, Sommers LE (1982) Total carbon, organic carbon and organic matter. In Methods of soil analysis. Part 2. Chemical and microbiological properties, ed. A.L. Page, R.H. Miller, and D.R. Keeney, 539-580. Madison, WI: ASA, SSSA

Olsen SR, Sommers LE (1982) Phosphorus. In: Page, A.L., Miller, R. H. and Keeney, D.R. (eds). Methods of Soil Analysis.Part 2. 2nd edn. Agronomy Series No. 9, American Society of Agronomy and Soil Science Society of America, Inc., Madison, WI, pp 403-430

Pote DH, Daniel TE, Sharpley AN, Moore PA, Edwards DR, Nichols DJ (1996) Relating extractable soil phosphorus to phosphorus losses in runoff. Soil Sci Soc Am J 60:855-859

Sharpley AN, Ahuja LR, Menzel RG (1981) The release of phosphorus to runoff in relation to the kinetics of desorption. J Environ Qual 10:386-391. https://doi.org/10.2134/jeq1981.004724250010000 30029x

Sharpley AN, Daniel TE, Edwards DR (1993) Phosphorus movement in the landscape. J Prod Agric 6:492-500

Sharpley AN, McDowell RW, Kleinman PJA (2004) Amounts, forms, and solubility of phosphorus in soils receiving manure. Soil Sci Soc Am J 68:2048-2057

Spargo J, Gregory TKE, Marcus MA (2006) Repeated compost application effects on phosphorus runoff in the Virginia Piedmont. J Environ Qual 35(6):2342-2351. https://doi.org/10.2134/jeq20 06.0105

Tarkalson DD, Mikkelsen RL (2007) Phosphorus losses in runoff after application of litter from broiler fed high available $\mathrm{p}$ corn feed. Commun Soil Sci Plant Anal 38:1805-1814. https://doi. org/10.1080/00103620701435571

Tejada M, Garcia-Martinez AM, Parrado J (2009) Effects of a vermicompost composted with beet vinasse on soil properties, soil losses and soil restoration. CATENA 77:238-247. https://doi. org/10.1016/j.catena.2009.01.004

Publisher's Note Springer Nature remains neutral with regard to jurisdictional claims in published maps and institutional affiliations. 